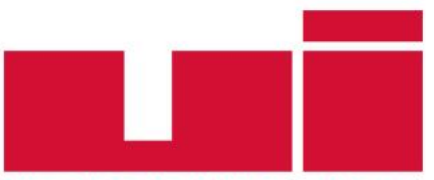

ULUSLARARASIILIȘKiLER

Akademik Dergi

Yayın ilkeleri, izinler ve abonelik hakkında ayrıntılı bilgi:

E-mail: bilgi@uidergisi.com.tr

Web: www.uidergisi.com.tr

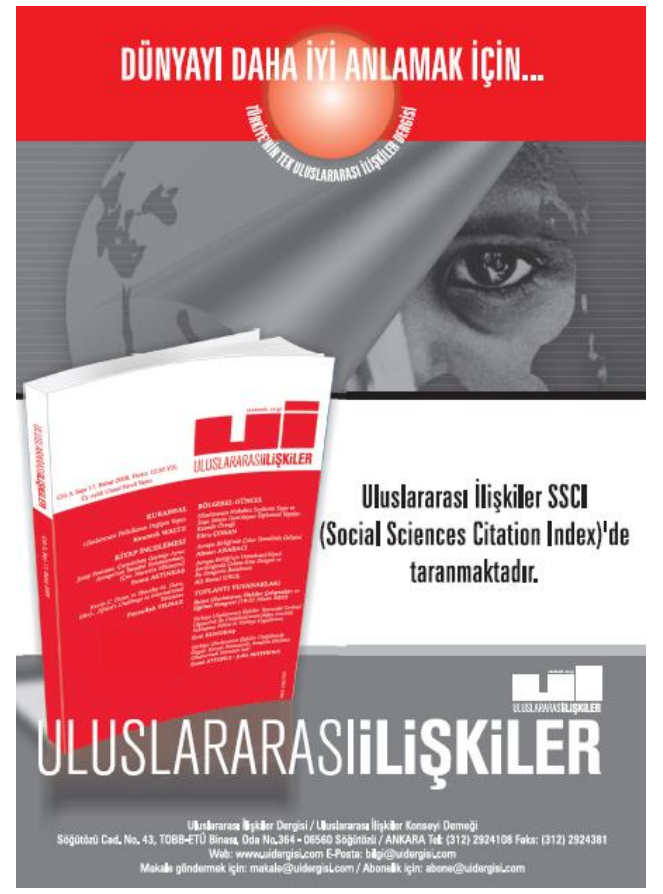

\title{
Kuzey Kore'nin Resmi İdeolojisi Olarak Cuçe Öğretisi ve Kuzey Kore Dış Politikasına Etkileri
}

\author{
Can KAKIŞIM* \\ * Yrd. Doç. Dr., Uluslararası İlişkiler Bölümü, Karabük \\ Üniversitesi
}

Bu makaleye atıf için: Kakışım, Can, “Kuzey Kore'nin Resmi İdeolojisi Olarak Cuçe Öğretisi ve Kuzey Kore Dış Politikasına Etkileri”, Uluslararası İlişkiler, Cilt 14, Sayı 56, 2017, s. 73-88.

Bu makalenin tüm hakları Uluslararası İlişkiler Konseyi Derneği’ne aittir. Önceden yazılı izin alınmadan hiç bir iletişim, kopyalama ya da yayın sistemi kullanılarak yeniden yayımlanamaz, çoğaltılamaz, dağıtılamaz, satılamaz veya herhangi bir şekilde kamunun ücretli/ücretsiz kullanımına sunulamaz. Akademik ve haber amaçlı kısa alıntılar bu kuralın dışındadır.

Aksi belirtilmediği sürece Uluslararası Illişkiler'de yayınlanan yazılarda belirtilen fikirler yalnızca yazarına/yazarlarına aittir. UİK Derneğini, editörleri ve diğer yazarları bağlamaz. 


\title{
Kuzey Kore’nin Resmî İdeolojisi Olarak Cuçe Öğretisi ve Kuzey Kore Dış Politikasına Etkileri
}

\author{
Can KAKIŞIM \\ Yrd. Doç. Dr., Uluslararası İlişkiler Bölümü, İİB, Karabük Üniversitesi, Karabük. E-posta: cankakisim@karabuk.edu.tr
}

\begin{abstract}
ÖZET
Kuzey Kore'nin resmî ideolojisi olan Cuçe öğretisi, ülkede yaşamın her alanına ve siyasetin işleyişine doğrudan etki eden kendine özgü bir fikir sistemidir. Bu ideoloji Kuzey Kore'de siyaset alanında tek adam egemenliğine dayalı, ekonomi alanında ise koyu biçimde devletçi ve izolasyoncu bir yapının kurulmasına neden olmuştur. Böylesi bir yapının ülkenin uluslararası ilişkilerine yansıması ise katı bir dış politika felsefesinin hâkimiyetidir. Kuzey Kore dış dünyaya şüpheci bir bakış açısıyla yaklaşmakta, dış politik amaçlarını gerçekleştirebilmek ve içeride Cuçe rejiminin devamını sağlayabilmek için nükleer silahlanmayı da içeren askeri öncelikli bir politikayı takip etmektedir.
\end{abstract}

Anahtar Kelimeler: Kuzey Kore, Cuçe, Sosyalizm, Askeri Öncelikli Politika, Nükleer Silahlanma

\section{Juche Doctrine as the Official Ideology of North Korea and Effects on the North Korean Foreign Policy}

\begin{abstract}
Juche, the official ideology of North Korea, is an original doctrine which influences every aspect of life and politics within the country. This ideology leads to one-man rule in the political area and highly statist and isolationist structure in the economic realm in North Korea. Effects of such an internal structure on the foreign relations of the country appear as the dominance of an uncompromising foreign policy philosophy. North Korea has a skeptical approach towards the external world and it pursues a military-first policy including nuclear armament in order to achieve its foreign policy goals and secure the continuation of Juche regime at home.
\end{abstract}

Keywords: North Korea, Juche, Socialism, Military-first Policy, Nuclear Armament 


\section{Giriş}

Kore Demokratik Halk Cumhuriyeti ya da daha fazla bilinen adıyla Kuzey Kore uluslararası akademik ve siyasi platformlarda en çok tartışılan ülkelerden birisidir. Ancak Kuzey Kore'nin bu "popülaritesi" ülkenin yüksek ekonomik performansı, ileri teknolojik düzeyi ya da demokrasi alanındaki başarılarından kaynaklanmamaktadır. Kuzey Kore'nin uluslararası politikada kilit bir yer tutmasını sağlayan unsur onun kendine özgü bir ideolojik yaklaşıma sahip olması ve bu düşünce çerçevesinde oluşturduğu yönetim mantığıdır. Cuçe adıyla anılan söz konusu ideoloji gerçekten de ülkeyi her bakımdan kontrolü altında tutmakta, devletin iç ve dış siyasetini en üst düzeyde etkilemektedir. Dolayısıyla Kuzey Kore'nin tüm dünyada ilgi uyandıran ve tartışmalar yaratan dış politik yönelimlerini kavrayabilmek için bu ideolojinin temel ilke ve kabullerine eğilmek şarttır.

$\mathrm{Bu}$ çalışmanın amacı Cuçe ideolojisini genel nitelikleriyle analiz edebilmek ve böylece bu öğretinin Kuzey Kore’nin dış politikasına hangi koşullarda etkide bulunduğunu gösterebilmektir. $\mathrm{Bu}$ amaç çerçevesinde makale üç asli kısma ayrılmıştır. Birinci bölümde Cuçe ideolojisinin ortaya çıkışı tarihsel bir bakış açısıyla ele alınacak, ayrıca bu öğretinin felsefi kökenlerine dikkat çekilmeye çalışılacaktır. İkinci bölümde ise $\mathrm{Cuçe} \mathrm{ideolojisinin} \mathrm{Kuzey} \mathrm{Kore'de} \mathrm{eskiden} \mathrm{beri} \mathrm{nasıl} \mathrm{uygulanagelmiş}$ olduğu irdelenecektir. Bu bölümde Cuçénin önce siyasi, sonra ekonomik ve son olarak da askeri alanlardaki pratiği üzerinde durulacaktır. Son bölümde ise Cuçe ideolojisinin Kuzey Kore'nin dış politikasına başlıca hangi noktalarda nüfuz ettiği ve nasıl yön verdiği anlatılacaktır. Bu bağlamda, Kuzey Kore’nin dışarıya bakışında hâkim olan yabancı karşıtı duruş, Güney Kore'yi eşit ve meşru bir devlet olarak tanımama eğilimi ve özellikle de tüm eleştirilere rağmen devam ettirdiği nükleer silahlanma politikasına vurgu yapılacaktır. Makalenin sonuç bölümünde ise çalışmada değinilen hususların üzerinden bir kez daha geçilecek ve son tespitler ortaya konulacaktır.

\section{Cuçe İdeolojisinin Tarihsel ve Felsefi Kökenleri}

Kuzey Kore devletinin resmî ideolojisi olan Cuçe (özgüven) öğretisi, ülkenin kurucusu ve "bilge lideri” Kim Il-sung'un dünya siyasi literatürüne kazandırdığı ve sahip olduğu prensiplerle ülkede yaşamın her alanına doğrudan ve güçlü biçimde nüfuz eden özgün bir fikir sistemidir. Cuçe düşüncesi temel hatlarıyla Kuzey Kore’nin kendi güç ve kaynaklarına dayanarak ve kendi içinde yeterli bir sistem kurarak, dışarıya bağımlılığını tamamen sıfırlaması gibi bir vizyona dayalıdır. Zira bireyin kendi kaderinin hâkimi olduğu anlayışından yola çıkan bu düşünce, geniş halk kitlelerinin gerekli biçimde eğitildikleri ve organize edildikleri takdirde herhangi bir dışsal müdahale ya da yardıma gereksinim duymadan başarılı bir devrim sürecini gerçekleştirebileceklerini varsaymaktadır. ${ }^{1} \mathrm{Bu}$ anlamda Cuçe öğretisi, “Büyük Güçler”e dayanarak gelişmeyi öngören yaklaşımların bir antitezi olarak azgelişmiş bir ulusa uluslararası koşullardan etkilenmeden bağımsızlı̆ııı sürdürebilmesi ve tüm eylemlerinde özgür davranabilmesinin formülünü verdiği iddiasına sahiptir.

Resmî kabullere göre, Kim Il-sung Cuçe düşüncesinin asli ilkelerini Japonya’ya karşı verilen antikolonyal mücadele sırasında geliştirmiştir. Il-sung parçası olduğu bu savaştan edindiği tecrübelerle Kore Devrimi’nin nasıl bir yön takip etmesi gerektiğini saptamış ve bu yöndeki fikirlerini antikolonyal mücadelenin önde gelen unsurları olan "Genç Komünistler Birliği” ile "Anti-Emperyalist Gençlik Birliği”nin Haziran 1930'daki toplantısında dile getirmiştir. ${ }^{2}$ Bununla birlikte, Cuçe öğretisi

1 Juche Idea: Answers to Hundred Questions, Pyongyang, Foreign Languages Publishing House, 2012, s.1.

2 Ibid., s.1. 
kayıtlara ilk olarak, sosyalist Kore Demokratik Halk Cumhuriyeti'nin kurulmasından yedi yıl sonra, Il-sung'un Aralık 1955'te yaptığı bir konuşmada geçecektir. Il-sung bu konuşmasında, Kore'de devrim sürecini ilerletebilmek için özgüvenli davranarak Kore'nin özgül koşullarını dikkate almak ve her alanda yerlileşmeye yönelmek gerektiğini belirtmiştir. ${ }^{3}$ Il-sung'un bu genel ifadelerle özetlediği Cuçe öğretisinin devlet politikası olarak şekillenmesi ise 1960 'larla birlikte gerçekleşecektir. ${ }^{4}$

Cuçe'nin resmî ideoloji olarak kabulünde tayin edici rol oynayan iki uluslararası gelişmeden bahsedilebilir. Birincisi Sovyetler Birliği'nde 1956'dan itibaren Stalin eleştirisinin güç kazanmasıdır. ${ }^{5}$ Kim Il-sung, tek adam yönetiminin yerine kolektif liderliği öngören bu sürecin, kendisinin Kuzey Kore'deki otoritesine de zarar verebileceğini düşünmüş ve bu eğilimin karşısında durmuştur. ${ }^{6} \mathrm{Bu}$ durumda Cuçe, Il-sung'un, liderliğini yeni bir ideolojik formülasyonla destekleme çabasının bir ürünüdür. Cuçe'nin devlet politikası haline gelmesinde etkili olan ikinci uluslararası gelişme ise 1960'lı yıllarda iyice su yüzüne çıkan Çin-Sovyet anlaşmazlığıdır. İdeolojik ve siyasi rekabette taraf olmaktan kaçınan ve iki ülkeye de belirli bir uzaklıkta kalmayı çıkarlarına uygun bulan Pyongyang yönetimi Cuçe öğretisinin ilkeleri ışığında kendi sosyalizm anlayışını inşa etmeye yönelecektir. ${ }^{7}$

Kim Il-sung'un Cuçe öğretisini geliştirirken dört temel kaynaktan etkilendiği söylenebilir. $\mathrm{Bu}$ kaynaklar Marksizm-Leninizm, Maoizm, Konfüçyüsçülük ve ulusal Kore gelenekleri ve milliyetçiliğidir. Il-sung Marksizm-Leninizm'den esas olarak proletarya diktatörlüğü ve dünya devrimi kavramları bağlamında faydalanmıştır. Proletaryayı toplumu kontrol altında tutacak ve yönlendirecek bir sınıf olarak inşa etme düşüncesi, Il-sung'un siyasi ajandası için son derece uygundur. Dünya devrimi kavramı ise dünyada kapitalist devletler var olduğu sürece bu diktatöryel yönetimin devamını garanti altına almaktadır ve Il-sung tarafından da bu sebeple kabul görmektedir. Aynı zamanda Sovyetler Birliği'nde ekonomi alanında izlenen devrimci politikalar da Il-sung için ilham verici niteliktedir. Özellikle Bolşevik yönetimin iktidarının ilk yıllarında yürüttüğ̈ millileştirme hamleleri ve merkezi planlı ekonominin tam anlamıyla kurulmasına yönelik adımları Kim Il-sung'un hararetle onayladığı ve göreve geldiğinde derhal hayata geçirmeye yöneldiği politikalar olmuştur. ${ }^{8}$

Maoizm'in Cuçe öğretisine etkisi ise her şeyden önce bu ideolojinin Avrupalı veya sanayileşmiş bir devlette değil, Kore gibi sömürge geçmişine sahip bir ülkede doğmuş olmasından kaynaklıdır. Zira iki ülkenin tarihsel tecrübeleri ve mevcut koşulları arasındaki benzerlik, Kim Il-sung'un Maoizm'i belirli yönlerden örnek almasına sebep olmuştur. Zaten Il-sung'un sosyalizmle tanışması da esas olarak 1931'de Çin Komünist Partisi’ne üye olmasıyla9 gerçekleşmiştir. Cuçe düşüncesinde özellikle kitlelerin seferberliğine verilen önem ve halk savaşı yürütecek bir halk ordusunun kurulmasına yönelik kabullerde Maoizm'den izler söz konusudur. Kimi yazarlar Maoizm'in lidere atfedilen rol noktasında da Cuçe öğretisine etkilerde bulunduğunu söylemekte ve Kim Il-sung'un kişi kültünü Mao'nun durumuna benzetmektedirler. Fakat bu noktada önemli bir fark vardır; Mao ulusunu savunan devrimci bir lider

3 Kim Il-Sung, "On Eliminating Dogmatism and Formalism and Establishing Juche in Ideological Work”, Kim Il Sung Works, Cilt 9, Pyongyang, Foreign Languages Publishing House, 1982, s.395-417.

4 Charles K. Armstrong, “'Fraternal Socialism': The International Reconstruction of North Korea, 1953-1962”, Cold War History, Cilt 5, No.2, 2005, s.162.

5 Yong Soo Park, "Policies and Ideologies of the Kim Jong-un Regime in North Korea: Theoretical Implications", Asian Studies Review, Cilt 38, No.1, 2014, s.6.

6 Bálazs Szalontai, Kim Il Sung in the Khrushchev Era, Stanford, Stanford University Press, 2005, s.85-88.

7 Soyoung Kwon, “State Building in North Korea: From A 'Self-Reliant' to A 'Military-First' State”, Asian Affairs, Cilt 34, No.3, 2003, s.292.

8 Paul French, North Korea: State of Paranoia, Londra, Zed Books, 2014, s.48-52.

9 North Korea Handbook, New York, M. E. Sharpe, 2002, s.841. 
görünümündeyken, Il-sung bir halka ulus olma vasfını kazandırmış bir figür olarak sunulmaktadır. Dolayısıyla Il-sung, Çin Halk Cumhuriyeti (ÇHC) örneğinden farklı biçimde, ulusal devrim ve kalkınma amaçlarında partinin öncülügüünden çok kendi tek adam rolünü ön plana çıarabilmiştir. ${ }^{10}$

Konfüçyüsçü düşünce ise Cuçe öğretisine esas olarak cemaat çıkarlarını bireysel çıkarların önüne koyma yönündeki eğilimi çerçevesinde katkıda bulunmuştur. Toplumu bir arada tutabilme ve yurttaşların bir bütün halinde birlikte hareket etmelerini sağlayabilme arayışında olan Kim Il-sung bu hususta, Marksist ya da Hegelci felsefeden daha fazla aşina olduğu Konfüçyüsçülükten önemli derecede etkilenecektir. ${ }^{11}$ Il-sung'un beklentilerine göre, toplumsal birliktelik düşüncesi özellikle Kore Savaşı'ndan sonra aciliyeti yüksek olan ulusal restorasyon çalışmalarının sürdürülmesi için de yarar sağlayacak, zaman içerisinde kurulacak ideal toplumun da temelini oluşturacaktı. Aynı zamanda merkezi planlı ekonominin kuruluşu ve düzenli bir biçimde işlemesi de çalışanların hem iş alanlarına hem de bizzat devletlerine karşı sorumluluk ve aidiyet hissi çerçevesinde hareket etmelerini, kendilerini yönetenlere sadakat ve itaat göstermelerini gerektirmekteydi. Böyle bir hissiyatın toplumda inşa edilmesi noktasında da Konfüçyüsçülük'ten faydalanma yoluna gidilecek ve bu düşünce Cuçe öğretisinin ana kaynakları arasında kendisine yer bulacaktır. ${ }^{12}$

Cuçe ideolojisinin son kaynağı ise ulusal Kore kültürü ve milliyetçiliğidir. Kore geleneklerinin Cuçe öğretisi üzerindeki etkisi kendisini en çok Kuzey Kore’nin hiyerarşik toplum yapısında göstermektedir. Zira antik Kore toplumu kast sistemine dayalıdır ve bu yapı sosyalist Kore'de de varlığını belli ölçülerde sürdürmektedir. Bu hiyerarşik yapı çerçevesinde toplumsal düzenin en üstünde elit bir yönetici grup ve Kore halkının cisimleşmiş hali olarak da ulusal lider vardır. Bu lider, korunmaya muhtaç derecede "saf ve masum" olduğu varsayılan Kore halkını himayesine alacak ve ona rehber olacaktır. ${ }^{13}$ Cuçe düşüncesinde Kore milliyetçiliğinin etkisi ise Japon emperyalizmine karşı verilen anti-kolonyal mücadele nedeniyle başlangıçtan beri güçlüdür. Kim Il-sung bu mücadele sırasında sosyalizm ve milliyetçiliği her zaman birlikte kullanmış ve $C u c ̧ e$ öğretisini geliştirirken de, sonrasında da bu birlikteliği sürdürmüştür. Bu milliyetçi ve yerliliği öne alan tavır uzun yıllar yabancı hâkimiyet altında kalan Kore halkında da doğal olarak karşılık bulacaktır. ${ }^{14}$

$\mathrm{Bu}$ kaynaklardan beslenerek gelişen Cuçe öğretisi bugün Kuzey Kore'de yönetim ve halkın önemli bir bölümünce üstün bir moral sistem olarak anlaşılmakta ve bu nedenle de istikrarlı bir biçimde tatbik edilmektedir. Bu öğretinin siyaset, ekonomi ve askeri alanlardaki uygulanışının daha ayrıntılı analizi konuyla ilgili fikir verici nitelikle olacaktır.

\section{Cuçe İdeolojisinin Uygulanışı}

\section{Siyaset Alanında Cuçe}

Cuçe ideolojisi, sömürgecilik ve emperyalizmi bilimsel olarak açılamak ve yukarıda da söylenildiği gibi azgelişmiş bir ülkenin bağımsızlı̆̆ını korumasının ve hızlı biçimde kalkınmasının nasıl mümkün olabileceğini saptamak gibi bir amaç doğrultusunda tasarlanmıştır. Tıpkı sosyalizmin komünizme

10 French, State of Paranoia, s.52-55.

11 Alzo David-West, "Between Confucianism and Marxism-Leninism: Juche and the Case of Chong Tasan", Korean Studies, Cilt 35, 2011, s.94.

12 French, State of Paranoia, s.58-60.

13 Michael Breen, Kim Jong-il: North Korea's Dear Leader, Singapore, John Wiley \& Sons, 2012, s.8.

14 Grace Lee, “The Political Philosophy of Juche”, Stanford Journal of East Affairs, Cilt 3, No.1, 2003, s.108-109. 
giden yolda bir geçiş aşaması olarak görülmesi gibi, Cuçe de eksiksiz bir ulusal bağımsızlığa giden yolun formülüdür. ${ }^{15} \mathrm{Bu}$ anlamda Cuçe öğretisinin siyaset alanındaki uygulanışı "Çacu” (bağımsızlık) ilkesine verilen büyük önem bağlamında şekillenmekte ve bütün siyasi hamlelerin bu kavramın gereksinimleri açısından belirlenmesinde kendisini göstermektedir. Böylesi bir yönelim ise, doğal olarak, öncelikle ideolojik anlamda bir bağımsızlık/ayrıksılık iddiasını ortaya koymaktadır.

Kim Il-sung Cuçe'nin Marksizm’in klasik kaynaklarına dayandığını kabul etmekte fakat bu öğretiyi Marksizm-Leninizm’i aşan bir teori olarak değerlendirmektedir. Zira Il-sung'un önemle belirttiği üzere Marksizm-Leninizm Kore gibi üretim güçlerinin gelişmemiş olduğu tarım toplumları için değil Batı́nın sanayileşmiş ülkelerine yönelik olarak geliştirilmiş bir ideolojik yaklaşımdır. Il-sung'un Cuçe'yi yaratmaktaki amacı ise Marksist-Leninist teoriyi Kore'nin ve onun gelişim seviyesindeki ülkelerin gerçekliklerine hitap eder hale getirmektir. Ona göre Cuçe'yi diğer bütün fikir sistemlerine üstün kılan da işte bu gerçekçi niteliğidir. Bu özelliğinden ötürü Cuçe, sadece Kore için değil diğer tüm azgelişmiş ülkelere de yeni bir yol olarak önerilmiş ve Üçüncü Dünya'da olabildiğince tanıtılmaya çalışılmıştır. Dolayısıyla esasında içe kapalı bir sistem de olsa, Cuçénin dışa dönük bir boyutu, enternasyonal bir iddiası da vardır. ${ }^{16} \mathrm{Bu}$ iddiayla paralel biçimde ve zaman içerisinde Marks, Engels ve Lenin'e yönelik atıflar resmî Cuçe metinlerinden çıartılacak, hatta sonrasında MarksizmLeninizm ve komünizm terimleri de bizzat Anayasa'dan dışlanacaktır. ${ }^{17}$

Kuzey Kore’de Cuçe öğretisi temelinde kurulan siyasi örgütlenme hakkında çeşitli ve birbirinden farklı tanımlamalar mevcuttur. Yong Soo Park, Kuzey Kore siyasi sistemi hakkında birçok araştırma yapılmış olsa da bu konuda geniş tabanlı bir uzlaşma olmadığını belirtmekte ve farklı araştırmacıların ülkeyi farklı sıfatlarla nitelemeyi tercih ettiğini dile getirmektedir. ${ }^{18}$ Fakat eğer Kuzey Kore siyasi sisteminin en ayırıcı özelliğinden bahsedilecek olursa bunun lidere kesin itaati öngören "Suryong" (lider) konsepti olduğunu belirtmek gereklidir. Monolitik bir yapı dâhilinde tüm siyasi otoritenin tavizsiz biçimde tek kişinin -yani suryong'un- elinde toplanmasına dayanan bu düşünce, organik toplum ilkesi çerçevesinde partinin, devletin ve bütün bir ulusun bilge bir liderin rehberliğinde yekvücut olarak hareket etmesini öngörmektedir. Zaten siyasi yapı da bu bilge liderin etrafında oluşturulan kişi kültüne dayalıdır. Bu minvalde, liderin kişisel nitelikleri ve başarıları abartılı biçimde ortaya konulmakta, onun fikirleri ve moral değerleri eğitim ve medya kanalları yoluyla halka devamlı olarak aktarılmakta, hatta liderin doğduğu gün ülkenin dönüm noktası ve en önemli ulusal bayramı olarak kabul edilmektedir. ${ }^{19}$ Bu noktada, Kore'de 1997 yılında miladi takvimin yerine kullanıma sokulan Cuçe takviminin Kim Ilsung'un doğumuyla başladığını hatırlamak anlamlı olacaktır. ${ }^{20}$

Kuzey Kore'de söz konusu bilge lider, başlangıçtan 1994’teki ölümüne dek Kim Il-sung, 2011'e kadar onun oğlu Kim Jong-il ve bu tarihten sonra da torun Kim Jong-un olmuştur. Kim Ilsung Cuçe öğretisinin kuramcısı olarak doğal liderdir. 1967'de Kim Il-sung'un kardeşi Kim Yong-ju tarafından formüle edilen ve 1974'te, o tarihte partinin teşkilatlanma ve rehberlik biriminin başında bulunan Kim Jong-il tarafından resmî program haline getirilen "Tek İdeoloji Sisteminin Kuruluşu için On İlke” başlıklı belge, Kuzey Kore halkı için Il-sung’a sadakati ideal davranış standardı olarak

15 French, State of Paranoia, s.45-46.

16 Ibid., s.49-50.

17 Jiyoung Song, "How Communist is North Korea? From the Birth to the Death of Marxist Ideas of Human Rights", Cambridge Review of International Affairs, Cilt 23, No 4, 2010, s.562.

18 Park, "Policies and Ideologies", s.5.

19 Ibid., s.5-6.

20 Andrew F. Wood ve David P. Terry, "The Only Dominator and Remaker of the World: <Self-Reliance>, <Unification>, and the Rhetoric of North Korean Juche", Western Journal of Communication, Cilt 80, No.4, s.507. 
ortaya koymak ve böylece Kim Il-sung'un hem parti içindeki hem de tüm ülkedeki tek adam rolünü sağlamlaştırmak amacıyla tasarlanmıştır. ${ }^{21} \mathrm{Bu}$ çerçevede Il-sung, ölümünden sonra "Ebedi Başkan" olarak ilan edilecektir. Kim Jong-il ise meşruiyetini Kim Il-sung'un "en önde gelen öğrencisi” ve Cuçe öğretisinin "en inançlı takipçisi” olmasından almıştır. ${ }^{22}$ Öyle ki Jong-il bu hususta Cuçe'nin formüle edilmesinde büyük katkıları olan, erken sosyalist Kore'nin ikinci adamı Hwang Jang-Yop'un da önüne geçmiştir. Bu anlamda Cuçe ideolojisinin varlığı Kim’lerin üç kuşaktır devam eden otoritesinin başlıca kaynağı olarak gözükmektedir, zira bir lidere yönelik ciddi bir kutsama durumu söz konusu olduğunda bu liderin soyundan gelenler de bu kişi kültünden doğal olarak faydalanmaktadır. Geçmişte Kim Jongil için geçerli olan bu avantaj sonraki dönemde Kim Jong-un'un liderliği için de gereken meşruiyeti sağlamıştır. Jong-un babasının ölümünün hemen ardından devlet medyası tarafından "Büyük Varis" ve partinin, ordunun ve halkın doğal lideri olarak lanse edilmiştir. ${ }^{23}$

Öte yandan Kuzey Kore'nin monolitik ve lider kültüne dayanan bu siyasi yapısı ülkede eskiden beri Kim ailesinin otoritesine karşı bir reform sürecinin istikrarlı biçimde devam etmesini engellemiştir. ${ }^{24}$ Kuzey Kore'de yumuşamaya dönük adımlar rejim tarafından yozlaşmış hamleler olarak anlaşılmaktadır. Ülkede ciddi bir istihbarat ağı hâkimdir ve uluslararası bilgi akışı da kontrol edilmektedir. Bu tavırla uyumlu olarak Kuzey Kore yönetimi Soğuk Savaş döneminde gerçekleşen 1956 Macar Ayaklanması ya da 1968 Prag Baharı gibi uluslararası gelişmeler karşısında daima muhafazakâr bir görüntü sergilemiştir. ${ }^{25}$

\section{Ekonomi Alanında Cuçe}

Cuçeöğretisinin ekonomi alanındaki ilke ve uygulamaları siyasi bağımsızlığın ülke içinde kendine yeterli bir ekonomik düzenin kurulmasıyla sağlanabileceği düşüncesi çerçevesinde anlam kazanmaktadır. “Çarip” terimiyle ifade edilen kendine yeterlik arayışı ise özerk gelişim kapasitesine sahip bir endüstriyel altyapının oluşturulmasını temel hedef olarak almakta, aynı zamanda tarımsal üretimin olabildiğince artırılmasına ve geliştirilmesine dayanmaktadır. Bu hedefler doğrultusunda Kuzey Kore'de başlangıçtan beri son derece sıkı bir merkezi planlama politikası uygulanacak ve ekonominin siyasi alandaki tam bağımsızlık hedefini destekleyebilecek bir düzeye getirilmesine çalışılacaktır. ${ }^{26}$

Kim Il-sung Kore'nin öznel şartlarından dolayı Marks'ın aşamalı devrim düşüncesini reddetmiş ve sosyalist ekonominin kurulması için kapitalist sürece ihtiyaç duyulmadığını, bu aşamanın atlanabileceğini savunmuştur. Il-sung’a göre işçilerle köylüler arasında niteliksel bir farklılık yoktur; önemli olan köylülerin başarılı biçimde proleterleştirilmeleridir. Bu amaca yönelik olarak bir taraftan devlet eliyle ağır sanayinin geliştirilmesine çalışılırken, diğer taraftan da kolektif çiftlikler kurularak köylüler fabrika işçileri gibi istihdam edilmeye başlanacaktır. ${ }^{27} \mathrm{Hem}$ sanayide hem de tarımsal üretimde azami verimin sağlanabilmesi için Kim Il-sung'un saha çalışmaları sonucunda geliştirdiği

21 “What are 'Ten Principles'?”, 9 Ağustos 2013, http://www.dailynk.com/english/read.php?cataId=nk02900\& num $=10829$ / (Erişim Tarihi 15 Nisan 2017).

22 Andrew Scobell, "Kim Jong Il and North Korea: The Leader and the System”, Charles W. Tarrington (der.), The Kim Jong Il Regime in North Korea, New York, Nova Science Publishers, 2009, s.21.

23 “North Korea Mourns Dead Leader, Son is 'Great Successor”, 19 Aralık 2011, http://www.reuters.com/article/uskorea-north-idUSTRE7BI05B20111219 (Erişim Tarihi 15 Nisan 2017).

24 Park, "Policies and Ideologies", s.7.

25 Barry Gills, "North Korea and the Crisis of Socialism: The Historical Ironies of National Division", Third World Quarterly, Cilt 13, No.1, 1992, s.128.

26 Ibid., s.111.

27 French, State of Paranoia, s.49-50. 
birbirine benzer iki ilkeden; sanayide "Tean" ve tarımda "Çonğsanri” yöntemlerinden faydalanılacaktır. $\mathrm{Bu}$ iki ilke de üretim sürecinde devlet yetkililerinin alt düzeydeki çalışanlara yardımcı olmalarını, sık sık çalışma sahalarına gitmelerini ve iş yerlerinde doğabilecek sorunları çalışanlarla bizzat görüşerek çözmelerini öngörmektedir. Bu anlamda Cuçe'nin işletme mantığı üretimin en alt düzeyde bile devlet görevlileri tarafından idare edilmesini gerektirmiş ve sonuçta büyük bir bürokratik yapıyı doğurmuştur. Böylesi bir yapı birtakım kısa vadeli getirilerine rağmen uzun vadede büyümeyi engelleyen yapısal sorunların ortaya çıkışına sebep olacaktır. ${ }^{28}$

Kore'nin kendine yetme düşüncesi dünya ekonomisinden izolasyonu beraberinde getirmiştir. Gerçekten de Kuzey Kore ekonomisi başlangıçtan itibaren büyük oranda yerli kaynakların mobilizasyonuna ve iç pazarın geliştirilmesine dayalıdır. Zira dünya ticaretine entegre olmanın Kore ekonomisine zarar vereceği ve ülkenin bağımsızlık amacını saptıracağı düşüncesinden hareketle uluslararası ticari ilişkiler asgariye indirilmiş, ülkeye doğrudan yabancı yatırımların girişinin önüne de kararlılıkla set çekilmiştir. ${ }^{29}$ Üstelik Kim ailesinin yurtiçi ve yurtdışı itibarını artıracağı düşünülen birtakım yüksek maliyetli ekonomik faaliyetlere girişilmesi de bu projelerin siyasi amaçlarla yürütüldüğünün kanıtı niteliğindedir. Başkent Pyongyang’a inşa edilen Cuçe Kulesi, Zafer Takı, Kim Il-sung Stadyumu gibi eserlerin ya da ev sahibi olunan belirli uluslararası etkinliklerin maliyetinin ulusal bütçeyi fazlasıyla zorlamış olduğu açıktır. ${ }^{30}$

Bununla birlikte Kuzey Kore yönetiminin, ciddi ekonomik sıkıntılardan dolayı özellikle 1970’lerde dış ticarete yöneldiği dönemler de olmuştur. 1970’li yıllar zaten Sovyetler Birliği ve ÇHC de dâhil olmak üzere sosyalist ekonomilerin kapitalist dünya ekonomisi ile teması artırdıkları bir zaman dilimidir. Bu bağlamda Kore, sermaye ve teknoloji transferi için özellikle Japonya ve Batı Avrupa ile kısıtlı da olsa ekonomik ilişkiler kurmuş ve bu girişimler Kore ekonomisine fayda sağlamıştır. ${ }^{31}$ Ancak bu kazanımlara rağmen, küresel ekonominin parçası olmanın ülkeyi dış etkilere karşı daha dayanıksız hale getireceği kabulünden hareketle bu ilişkiler düşük düzeyde tutulmuştur. Zira Kuzey Kore'nin sınırlarını ticarete ve yatırıma açmasının rejimin Kim ailesinin kültüne dayanan meşruiyetine zarar vereceği düşüncesi Kore yönetiminde güçlüdür. ${ }^{32}$ Ayrıca Kuzey Kore üzerinde, siyasi çizgisinden dolayı, etkili çok taraflı yaptırım ve kısıtlamalar söz konusudur.

Bugün Kuzey Kore'de kronik bir kıtlı sorunu vardır. Öyle ki bu sorun 1995-1999 yılları arasında 600 bin ila 1 milyon kişinin ölümüne sebep olacak derecede ciddi boyuttadır. Ülkede toprağın sadece yüzde 20'si ekilebilir durumdadır, ayrıca iklim şartları da tarımsal üretimi çok olumsuz biçimde etkilemektedir. Dolayısıyla ekonominin görece iyi olduğu dönemlerde dahi Kuzey Kore kendisini besleyebilen bir ülke olamamıştır ve ekonomik varlı̆̆ını Soğuk Savaş’ın sonuna kadar Sovyetler Birliği, daha sonra ise ÇHC’nden gelen dış yardımlara bağlı olarak sürdürmektedir. Bu anlamda yapılan kendi kendine yetme propagandasına rağmen Kore'nin bu iddiası gerçekçi olmaktan uzaktır. ${ }^{33}$ Eldeki veriler ışığında sosyalist Kore'nin hızlı kalkınan ya da halkının refah seviyesini istikrarlı olarak artıran bir ekonomik yapı kurabildiğini söylemek mümkün değildir. Söz konusu ekonomik yapı Cuçe’nin siyasi anlayışının uzantısı olduğu için bu yapının yönetime hâkim olan temel felsefe değişmeden kayda değer bir revizyona uğraması da son derece zor gözükmektedir.

28 Gills, "Crisis of Socialism”, s.114.

29 Scobell, "Kim Jong Il and North Korea", s.75.

30 Park, "Policies and Ideologies", s.6-7.

31 Gills, "Crisis of Socialism”, s.116.

32 Alan Kang, “The Lens of Juche: Understanding the Reality of North Korean Policymakers”, The Review of International Affairs, Cilt 3, No.1, 2003, s.53.

33 Andrew Logie, The Answers: North Korea, Singapore, Marshall Cavendish, 2012, s.20. 


\section{Askeri Alanda Cuçe}

Tam bağımsızlık ilkesini resmî öğretisinin temeline yerleştiren Kuzey Kore, bu amacı sadece ideolojik yerlilik ya da ekonomik izolasyon politikalarıyla değil, belki onlardan da fazla, sert güce (hard power) dayalı yöntemlerle başarmaya çalışmaktadır. Bu kapsamda, Kore'nin uluslararası siyasi hamleleri önemli ölçüde askeri meselelere verilen öncelik bağlamında şekillenmektedir. Bu eğilimi Cuçe öğretisinin temel bileşenlerinden olan "Çavi” (öz savunma) ilkesinde tüm açıklığıyla görebilmek mümkündür. Kore'de askeri meselelere verilen önemin teorik altyapısını oluşturan bu ilke, orduyu toplumsal gruplar arasında en üste yerleştirmekte, ona işçilik ve köylülükten daha yüksek bir statü tanımaktadır. Kim Il-sung'un gerilla geçmişi düşünüldüğünde, hele ki Kore yarımadasının bölünmüşlük şartları hesaba katıldığında bu tavır şüphesiz ki şaşırtıcı değildir. $\mathrm{Bu}$ yaklaşım aynı zamanda Kuzey Kore'nin dünya devrimi anlayışıla da uyumludur. Cuçe öğretisinin kabullerine göre yeryüzünde emperyalist ülkeler var olmaya devam ettikçe büyük bir askeri gücün mutlaka elde tutulması gerekmektedir. ${ }^{34}$

Bununla birlikte zaman içerisinde Kuzey Kore’nin bu yaklaşımı daha da keskinleşecek ve askeri konulara yönelik hassasiyet belirli gelişmelere tepki olarak iyice artacaktır. Örneğin Güney Kore hükümetinin Japonya ile 1965 yılında ayrı bir barış anlaşması imzalaması ve Vietnam Savaşı’na da muharip birlikler sevk etme kararı alması üzerine Kim Il-sung, ulusal savunmaya öncelik verecek bir ekonomik yapılanma konsepti geliştirmiş ve bu yöndeki projesini Ekim 1966'daki Parti Temsilcileri Konferansı'nda kabul ettirmiştir. Bu plan uyarınca, Kuzey Kore'de askeri harcamalar yükselmiş ve ulusal bütçeyi zorlayacak bir düzeye ulaşmıştır. Öyle ki bu kararın bir sonucu olarak 1961-1967 yılları için ortaya konulan "Yedi Yıllık Plan" başarısız olmuş ve öngörülen sonuçların elde edilebilmesi için süresi üç yıl daha uzatılmıştır. ${ }^{35}$ Kore'nin Vietnam Savaşı'na müdahil olarak sosyalist Kuzey Vietnam rejimine malzeme yardımı yapma kararı alması ve Güney Kore'deki devrimci hareketleri destekleme politikası izlemesi söz konusu maliyeti daha da artırmıştır.

Fakat Kim Il-sung yönetiminin askeri meselelere gösterdiği ilgiye karşın bu yöndeki eğilimin daha da güçlendiği süreç, ardılı Kim Jong-il’in iktidar dönemidir. Kim Jong-il, babası Kim Ilsung öldükten sonra Kore İşçi Partisi’nin (KİP) Genel Sekreteri ve Devlet Başkanı olarak hemen atanmamış, hatta ülkede parti ya da meclis seçimleri bir süre yapılmamıştı. Bu anlamda Kore'nin siyasi geleceği Kim Il-sung'un ölümünü izleyen birkaç ay boyunca muğlak bir konu olarak kalmıştı. ${ }^{36}$ Ayrıca 1990'ların başında Kuzey Kore'yi yakından ilgilendiren büyük iç ve dış krizler söz konusuydu: Soğuk Savaş düzeninin sosyalist bloğun yenilgisiyle sonlanması, $\mathrm{ABD}$ ile süregelen gergin ilişkiler ve ülkede yaygın kıtlığa sebep olan doğal felaketlerin ardı ardına yaşanması. Bu faktörler Kuzey Kore liderliğinin istikrarını tehdit eder hale gelmişti. ${ }^{37}$ Böylesi bir ortamda Kim Jong-il hem kendi otoritesini tam olarak tesis edebilmek hem de Cuçe rejiminin devamlılığını sağlayabilmek amacıyla kendisine mutlak sadakat gösteren ordunun merkezinde olduğu bir kriz yönetimi sistemini kurmaya yönelmiş, bu da "Songun" kavramıyla ifade edilen "askeri öncelikli politika” ya zemin hazırlamıştır.

1995 'te resmî olarak kabul edilen askeri öncelikli politika, Kore’de ordunun güç ve kapasitesinin olabilecek en üst düzeye çıkartılmasını, ülkenin siyasi, ekonomik ve diplomatik politikalarının askeri ihtiyaçlar temelinde şekillendirilmesini ve bu çerçevedeki kararların büyük

34 French, State of Paranoia, s.46.

35 Gills, "Crisis of Socialism”, s.115.

36 Kwon, "State Building in North Korea”, s.294.

37 Park, "Policies and Ideologies", s.8. 
oranda ordu yetkilileri tarafından alınmasını öngörmektedir. Bu doğrultuda ordu mensupları devlet yönetiminde ayrıcalıklı kılınarak, askerler partinin karar alma mekanizmasında en önemli mevkilere getirilmeye başlanmıştır. Kuzey Kore liderliği ordu mensuplarına halk hareketlerini yakından izleme görevini vererek, militarist ruhun halk kitlelerine aşılanması hususunda orduyu tam yetkili kılmıştır. ${ }^{38}$ Ordunun statüsünü ve başkomutanın otoritesini yükseltmeye dönük yapısal ve kurumsal değişiklikler 1990'larda imza atılan anayasa değişikliklerine açıkça yansımıştır. Ordunun başında Başkomutan vasfıyla Kim Jong-il vardır ve bu anlamda ülkede ipleri Kim Il-sung'un bıraktığı noktadan devralmıştır. ${ }^{39}$

Ordunun ve militarist ruhun devlet ve toplum katında güçlü olduğu böylesi bir siyasi ortamda ekonomik reform ihtiyaçları önemli ölçüde ihmal edilmiştir. Ordu hem nicelik hem de niteliksel açıdan güçlendirilmiş, hatta nükleer silahlar ve uzun menzilli füzeler de dâhil olmak üzere üst düzey silahlarla donatılmıştır. Ancak bu askeri yatırımların etkisiyle Kuzey Kore kendi halkını besleyemeyen bir ülke durumuna düşmüştür. ${ }^{40}$ Kuzey Kore'de askeri harcamalar ulusal bütçenin üçte birlik bir bölümünü oluşturmaktadır ve bu durum Kore'de kitlesel fakirliğin en önemli sebeplerinden biridir. ${ }^{41}$ Kısacası, Kim Jong-il, Kim Il-sung'un öngördügü Cuçe devletini güçlü bir askeri yapı kurarak desteklemiş, ancak bunun kitleler üzerindeki faturası yıkıcı bir karakterde olmuştur. ${ }^{42}$

\section{Cuçe İdeolojisinin Dış Politikaya Etkileri}

\section{Yabancı Karşıtı Duruş}

Cuçe öğretisinin fikri kaynaklarından biri olduğu yukarıda belirtilen Kore milliyetçiliği Kuzey Kore devlet politikalarında güçlü biçimde varlığını sürdürmektedir ve bu anlamda bu öğretinin asli niteliklerinden biri konumundadır. Cuçe öğretisi idari yönden merkeziyetçi ve ekonomik olarak dışa kapalı olduğu gibi, siyasi felsefe açısından da milliyetçi bir karakter arz etmektedir. "Saf ve erdemli" üstün bir Kore ulusu tasavvuruna dayanan Kuzey Kore milliyetçiliği etnik temellidir. Bu noktada Han S. Park, Cuçe rejiminin milliyetçi politikalarını Kore halkının etnik açıdan homojen olduğu kabulüne dayanarak sürdürdügünü ve halk kitleleri arasında bir ulusal gurur duygusu yaratmaya çalıştığını, eğitim ve medya kanalları yoluyla da bu yönde propaganda faaliyeti yürüttügünü kaydetmektedir. ${ }^{43}$ $\mathrm{Bu}$ yaklaşıma göre, Kuzey Kore yönetimi yabancı karşıtı, hatta kimi zaman açıkça ırkçılığa kayan bir duruş sergileyen bir rejim görünümündedir.

Kuzey Kore'deki söz konusu bakış açısı ülkenin dış politikasına da doğrudan etki etmektedir. Zira ırk temelli bu yaklaşım Kuzey Kore halkını saf ve erdemli olarak tanımlarken bunun olumsuzu niteliğindeki “öteki” nin de kurgulanması gerekmektedir. Kuzey Kore yönetiminin yaklaşımında ÇHC, Rusya, Suriye, İran gibi bazı istisnalar dışında çok sayıda devlet bu kapsama girmektedir. Fakat, Kuzey Kore'nin resmî politikasında dost ülke olarak tanımlanan, Laos gibi son derece yakın ilişkilerin söz konusu olduğu ülkelere yönelik olarak dahi küçümseyici bir tavır ortaya konulabilmektedir. Bu ülkeler, Kuzey Kore'ye bağımlı ve Cuçe politikalarının edilgen birer uygulayıcısı olarak pejoratif biçimde tasvir

38 Ibid., s.8.

39 Kwon, "State Building in North Korea”, s.294.

40 Park, "Policies and Ideologies", s.8.

41 Gills, "Crisis of Socialism”, s.115.

42 Kwon, "State Building in North Korea”, s.294.

43 Han S. Park, North Korea: The Politics of Unconventional Wisdom, Boulder, Lynne Rienner, 2002, s.70. 
edilebilmektedir. Bununla birlikte, söz konusu zenofobik tavrın en fazla ABD ve Japonya’ya yönelik olarak sergilendiğini belirtmek gereklidir. ${ }^{44}$

Japonya'ya yönelik tepki, bu ülkenin Kore’deki sömürgeci geçmişinden kaynaklanmaktadır. Japonya’nın Kuzey Kore’ye 1990’lı yıllarda yaptığı insani yardımlara ${ }^{45}$ rağmen sosyalist Kore yönetimine karşı başlangıçtan beri izlenen muhalif politikalar bu anlayışı daha da güçlendirmiştir. Amerikan karşıtı kampanyanın temel dayanağı ise ABD’nin Kore Savaşı sırasında sergilediği kimi olumsuz eylemler ile sonrasında Amerika'nın kapitalist dünyanın lideri olarak kabul edilmesidir. Kuzey Kore'deki resmî milliyetçilik anlayışı üzerine araştırmalar yapan Brian Reynolds Myers'in değerlendirmesiyle Amerikalılar ve Japonlar yayılmacı hırsları asla değişmeyecek kötü tabiatlı haklar olarak kabul edilmekte ve bu anlamda Kore halkının daimî düşmanları olarak sunulmaktadır. ${ }^{46}$

Kuzey Kore'nin dünyaya bakış açısında, belli istisnalar dışında, çok sayıda ülkeye yönelik olumsuz bir tavır söz konusu olmakla birlikte, Amerikan ve Japon halklarının kötü yaradılışlı olduklarına dair kabulün ülkedeki yabancı karşıtlı̆̆ının baş dayanağı olduğu ileri sürülebilir. Öyle ki resmî yayınlarda ve kamuya açık alanlarda yer verilen belirli yazı, poster ve tablolarda "saf ve iyi" Kuzey Koreliler ile "kötü ve uğursuz" yabancıların birbirine zıt algılanışlarını açıkça görebilmek mümkündür. Michael Breen, bu anlamda sadece yabancı devlet görevlilerine ve siyasetçilere değil, bu ülkelerden Kuzey Kore'ye turist olarak gelen sıradan insanlara da potansiyel suçlular olarak şüpheyle bakıldığını vurgulamaktadır. ${ }^{47}$

Üstelik Kuzey Kore yönetiminin Amerikalılara yönelik olumsuz algısında Hıristiyanlık karşıtı bir temanın da etkili olduğu yine dile getirilen hususlardan biridir. Bu yorumlara göre Kuzey Kore yönetimi, Hıristiyanlığın misyonerlerce dünyanın farklı bölgelerine sızmak ve yerel hükümetleri devirmek için kullanılan bir araç olduğu yönünde bir kabule sahiptir. ${ }^{48} \mathrm{Bu}$ anlamda Kuzey Kore'de misyonerlik faaliyetleri iktidar tarafından katı biçimde kınanmış ve ABD’nin misyonerlik faaliyetleri kapsamında yürüttügü kimi yardım programlarının da uluslararası imaj çalışmasından ibaret olduğu kabul edilmiştir. Myers, Kore yönetiminin ABD'yi ahlaksızlıkların kaynağı olarak değerlendirdiğini, hatta eşcinselliği bir Amerikan "sapkınlığı" olarak sunduğunu belirtmektedir. ${ }^{49}$ Pyongyang yönetimime göre bu gibi yabancı kültürel etkiler Kore'nin ulusal kültürünü yozlaştırmayı amaçlayan bir istila mekanizması niteliğindedir ki bu kültürün bozulması Kore ulusunun da yok olması anlamına gelmektedir. ${ }^{50}$ Kim Jong-il'in Hollywood sinema yapımlarına düşkünlüğ̈̈ ${ }^{\bigotimes}$ ve Kim Jong-un'un Amerikan basketbol ligi NBA’e yönelik ilgisis ${ }^{51}$ hesaba katıldığında ülkede bu tür bir anlayışın varlığı şüphesiz ki ironiktir.

"Habis” düşmanlarla çevrili bir ortamda yabancı karşıtlığına dayalı bir politikayı sürdürmek, Kuzey Kore yönetimi tarafından "dış tehditlere karşı halkı korumak" söylemiyle meşrulaştırılmaktadır. Batılı devletlerin Kuzey Kore'yi şer ekseninde (axis of evil) ya da haydut devlet (rouge state) biçiminde tanımlayan ulusal güvenlik stratejileri takip etmeleri Pyongyang yönetiminin bu söylemine katkı sağlayan

44 Brian Reynolds Myers, The Cleanest Race: How North Koreans See Themselves, New York, Melville House Publishing, 2010, s.129-131.

45 David Fouse, “Japan's Post-Cold War North Korea Policy: Hedging toward Autonomy?”, Asian Affairs, Cilt 31, No.2, 2004, s.109.

46 Myers, The Cleanest Race, s.131-136.

47 Breen, Kim Jong-il, s.99-100.

48 Myers, The Cleanest Race, s.136.

49 Ibid., s.138-139.

50 Jae-Jung Suh, "Making Sense of North Korea: Juche as An Institution”, Jae-Jung Suh (der.), Origins of North Korea's Juche: Colonialism, War, and Development, Lanham Md, Lexington Books, 2013, s.15-16.

51 "Dennis Rodman, NBA Old-Timers Arrive in North Korea for Basketball Game", 6 Ocak 2014, http://edition.cnn. com/2014/01/06/world/asia/north-korea-dennis-rodman/ (Erişim Tarihi 15 Nisan 2017). 
bir zemin hazırlamaktadır. Özellikle ABD'de 2001 yılında George W. Bush yönetiminin işbaşına gelmesi Kore yönetiminin yabancı karşıtı duruşunu ve bu yöndeki propagandasını güçlendirmiştir. Bu süreçte, ABD ile Güney Kore arasında yakın ilişkilerin kurulması ve bu ülkelerin Kuzey Kore’ye yönelik sert tavır takınmaları Cuçe rejiminin zenofobik politikalarına etkili bir dayanak noktası sunmuştur.

\section{Güney Kore'yi Gayrimeşru Bir Devlet Olarak Tanıma}

Kim Il-sung, kişi kültünü sadece Kuzey Kore'nin değil bütün bir Kore halkının kurtuluşu ve bağımsızlı̆̆ının sağlanmasından sorumlu bir lider profili üzerine inşa etmiş, Güney Kore yönetimini ise en başından beri tartışmasız biçimde gayrimeşru bir siyasi otorite olarak tanımlamıştır. Kuzey Kore devlet adamlarının gözünde Seul yönetimi Cuçe’nin öngördüğü devlet modelinin antitezi olarak kabul edilmekte ve bu sebeple de "itaatkârlık" ya da "başkalarına dayanma" anlamına gelen "Sedecui" terimiyle eşleştirilmektedir. ${ }^{52}$ Bu özellikleriyle Güney Kore devleti Kuzey Kore'nin bir eşiti olarak değerlendirilmemektedir. Bu devlet varlığını Kore Savaşı'na borçlu, kukla bir yapı, hatta doğrudan Amerikan kolonisi olarak kabul edilmektedir. Kore Savaşı, Kuzey Kore'de "Anayurdu Kurtarma Savaş” olarak bilinmekte ve Amerikan emperyalistleri ile onların Koreli işbirlikçilerine karşı verilen kahramanca bir mücadele olarak sunulmaktadır. Kuzey Kore yönetimi, savaşı, bir galibi olmamasına rağmen verdikleri mücadele sayesinde Amerikalıların bütün bir yarımadayı sömürgeleştirme amacının boşa çıkarıldığını ifade ederek, bir zafer olarak adlandırmaktadır. Ancak yarımadanın yarısı hala denetim dışında olduğundan savaş henüz bitmemiştir. ${ }^{53}$ Kuzey Kore yönetimi ise bu bölünmüşlüğü ve yozlaşmış durumu giderebilecek olan yegâne siyasi yapıdır. Bu bakış açısı KİP’in resmî bir metninde şu ifadelerle açıkça ortaya konulmuştur: "KİP ülkemizin güney yarısının Amerikan emperyalist saldırı güçlerinden ve gerici iç yönetimden kurtarılması, Kuzey ve Güney’in geniş kitlelerini kesin biçimde birleştirerek ülkenin tam birliğinin demokratik bir temelde sağlanması için mücadele edecektir." ${ }^{54}$

$\mathrm{Bu}$ alıntıdan da anlaşılabileceği üzere Kuzey Kore, Güney’le yeniden birleşmenin ancak kendi sosyalist şartlarında gerçekleşebileceği yönündeki arzusunu hiçbir zaman terk etmemiştir. Dolayısıyla, Koreli yöneticiler için birleşme amacı sadece ülkenin bütünlüğünü sağlamak değil, tüm Kore toplumunun $\mathrm{Cuçe} \mathrm{ideolojisinin} \mathrm{nüfuzu} \mathrm{altına} \mathrm{alınması} \mathrm{anlamına} \mathrm{gelmektedir.}{ }^{55}$ Kuzey Kore'nin konvansiyonel araçlar dışında yürüttüğü askeri öncelikli politika, tutarlı biçimde sürdürülen bu amacı açığa vurmaktadır. Kuzey Kore sahip olduğu sert güç kapasitesine dayanarak birleşme konusunda kuralları koyan taraf olma hakkını kendinde görmektedir. Cuçe rejiminin önde gelen sözcülerinden Kim Myong Chol'un şu ifadeleri bu yaklaşımı net olarak işaret etmektedir: "Güney Kore'nin tarih sahnesinden çekilme zamanı gelmiştir, onun mimarı ve ebeveyni ABD dahi Kuzey Kore ile normalleşme yolları aramaktadır. Güney Kore, Kuzey'in ... sahip olduğu ulusal ehliyetten ve meşruiyetten tümüyle yoksundur. ${ }^{\text {‘6 }}$ Böylesi bir durumda, Güney Kore'nin ortadan kalkmasının yaratacağı boşluk da hiç şüphesiz ki Kuzey Kore yönetimi tarafından doldurulacaktır. Güney Kore'nin birleşme konusundaki politikaları hükümetten hükümete kısmi farklılıklar göstermiş olsa da, Kuzey Kore'nin bu hususa yönelik tavizsiz yaklaşımı geçmişten beri sabit kalmıştır. ${ }^{77}$

52 Kang, "The Lens of Juche”, s.52.

53 Armstrong, Tyranny of the Weak: North Korea and the World, 1950-1992, New York, Cornell University Press, 2013 , s.14.

54 Kang, "The Lens of Juche", s.48-49.

55 A Comparison of Unification Policies of South and North Korea, Seul, National Unification Board, 1990, s.38-39.

56 Kang, "The Lens of Juche”, s.49.

57 Huh Moon Young et.al., Basic Reading on Korean Unification, Seul, Korea Institute for National Unification, 2012, s.67. 
Pyongyang yönetimi açısından Cuçe’nin öngördüğ̈ koşullarda birleşmenin ilk şartı her zaman Amerikan askerlerinin Güney Kore sınırından çekilmesi olmuş, bu önkoşul 1950’li yıllardan bugüne dek kesintisiz biçimde dile getirilmiştir. Zira Kuzey Kore yönetimine göre "Güney Kore’yi zorla işgal eden Amerikan birlikleri ve onların yolundan giden sömürgeci faşist rejim Kore halkının bağımsız birleşmesini engelleyen kanserli hücreler"dir. ${ }^{58}$ Bununla birlikte, Amerikan askerlerinin Kore'den çekilmesi Kuzey Kore'nin bölgedeki askeri varlığını güçlendirecek ve dolayısıyla Pyongyang'ın pazarlık şansını artıracak, hatta siyasi amaçları gerçekleştirmek için askeri operasyon seçeneğini daha kuvvetli bir ihtimal haline getirecektir. Çünkü ABD-Güney Kore savunma ittifakı, Kuzey Kore'ye karşı çift taraflı caydırıcılık yaratan bir unsurdur. O halde Amerikan askerlerinin böylesi bir geri çekilişinin en olası sonucu Güney'i Kuzey karşısında daha dayanıksız kılmak olacaktır. ${ }^{59}$

1970’ler bu örtülü amacın açıkça dile getirildiği bir dönemdir. Öyle ki Kim Il-sung 1976 ve 1978 yılları arasında ABD Başkanı Jimmy Carter’a yazdığı çok sayıda mektupta ateşkesin yerine bir barış antlaşması imzalanmasını talep etmiş, bu hususta iki şart öne sürmüştür: Amerikan askeri varlığının Kore'den çıkarılması ve Güney Kore'nin söz konusu barış görüşmelerinden dışlanması. Seul yönetiminin barış görüşmelerine katılımını engelleme arzusu Kuzey Kore'nin bu ülkeyi atlayarak $\mathrm{ABD}$ ile ikili ilişki kurma niyetine işaret etmektedir. Bu da ABD’nin askeri geri çekilişi için gerekli görüşmelerin, meşru ve eşit bir yapı olarak görülmeyen Güney Kore hükümetinin herhangi bir etkisi olmadan yürütülmesi anlamına gelmektedir. Bu yönelim, Kuzey Kore'nin Aralık 1991'de Güney Kore ile imzaladığı saldırmazlık paktını da kısmen açıklayan bir unsurdur. Bu anlaşmanın imzalanmasındaki amaç, görüşmelerin ileriki aşamalarında yine $\mathrm{ABD}$ ile çift taraflı bir uzlaşmayı sağlayabilmek olarak göze çarpmaktadır. Kaldı ki Kuzey Kore, Amerikan birliklerinin çekilmesini yeterli bulmamakta, ABD-Güney Kore askeri ittifakının ilgasını talep etmektedir. Kuzey Kore'nin, 1970'lerde Carter'ın Amerikan birliklerinin çekilmesini kabul etmesine karşlık tüm Amerikan hava araçlarının geri çekilmesinin yanı sıra ABD ile doğrudan görüşmeler yürütme yönündeki ısrarlı taleplerini sürdürmesi bu noktada anlamlı bir örnektir. ${ }^{60}$

Cuçe öğretisi sadece Kuzey'de değil bütün bir Kore yarımadasında mutlak bağımsızlığı ve yerelliği öngörmektedir. Bu anlamda Kuzey Kore siyaset yapıcıları için Güney Kore'yi dış etkilerden “özgürleştirmek” bu amaca ulaşmakta kilit bir aşamadır. Söz konusu özgürleşmenin sağlanabilmesi ise birleşmenin Kuzey’in belirlediği şartlarda olmasına bağlıdır. Bu husus, Kuzey Kore'deki sistemin devamı ve istikrarı için de asli önemdedir, zira kapitalizm koşullarına uyumlu bir ülkeyle onun şartlarında birleşilebileceğine inanmak Cuçe ideolojisinin bütün meşruiyetini ve tutarlılığını da gözden çıarmak anlamına gelecektir. Bu hususlar çerçevesinde, Kuzey'in Güney’e yönelik adımlarını eşit koşullarda bir birleşmeye dönük hamleler olarak değerlendirmek gerçekçi değildir.

\section{Nükleer Silahlanma Çalışmaları}

Kuzey Kore'de nükleer silahlanma programına yönelik ilgi 1950’lere dayanmaktadır. Radyoaktif enerjinin tarım, endüstri ve tıp alanlarında kullanımı ile ilgili araştırmalar yapmak amacıyla bir Atom Enerjisi Araştırma Enstitüsü 1952'de kurulmuş, aynı zamanda çok sayıda öğrenci Sovyetler Birliği’ne eğitime gönderilerek nükleer enerjiyle ilgili üst düzey eğitim almaları sağlanmıştır. ${ }^{61}$ Kuzey Kore,

58 Kang, "The Lens of Juche”, s.49.

59 Ibid., s.49-50.

60 Ibid., s.50.

61 Benjamin Habib, "Rogue Proliferator? North Korea's Nuclear Fuel Cycle \& Its Relationship to Regime Perpetuation", Energy Policy, Cilt 38, No 6, 2010, s.2831-2832. 
takiben, nükleer enerjinin savunma alanında kullanılması için harekete geçerek Sovyetler Birliği ve ÇHC’nden nükleer silahlanma konusunda yardım istemiş fakat beklediği karşılığı bulamamıştır. Bununla birlikte, bu iki ülke silahlanma konusunda olmasa da nükleer enerjinin kullanımıyla ilgili birtakım yardımlarda bulunmayı kabul ederek Kore'de çeşitli nükleer tesislerin inşa edilmesinde rol üstlenmişlerdir. 1950’li ve 60’lı yıllar Kuzey Kore'nin nükleer enerjiyle tanıştığı bir zaman dilimi olarak öne çıkmaktadır.

Kuzey Kore'nin kendi nükleer silahlanma programını hayata geçirmek için çalışmalara başladığı dönem 1980 sonrası dönemdir. Pyongyang yönetimi, taraf olduğu Nükleer Silahların Yayılmasını Önleme Antlaşması'nın (NPT) Uluslararası Atom Enerjisi Kurumu ile gerektirdiği belirli ek sözleşmeleri imzalamaktan kaçınmış ve bu nedenle de uluslararası toplumun artan tepkisini üzerine çekmeye başlamıştır. Sorunun çözümü için ABD'nin devreye girmesi sonrasında 1994'te imzalanan Çerçeve Anlaşma, bu konuda geçici bir yumuşamaya sebep olmuştur. Bu anlaşma, ABD’nin Kuzey Kore’ye enerji amaçlı kullanılacak iki hafif su reaktörü kurması ve bu ülkeye ABD, Güney Kore ve Japonya'nın yapacağı benzin yardımı karşılığında Cuçe rejiminin nükleer politikasını terk etmesini öngörmekteydi. Ancak ABD’nin gereken benzin yardımını yapmasına karşın su reaktörü kurma planı ABD Kongresi'nden onay alamamıs, ayrıca kamuoyunda oluşan muhalefet neticesinde hem Clinton hem de Bush yönetimleri Kore ile yumuşama politikasından geri çekilmeye başlamışlardır. Sonuçta süreç akim kalmış ve nihayetinde 2002 yılıyla birlikte ABD resmî olarak görüşme masasından kalkmıştır. Kuzey Kore, bu gelişme üzerine Ocak 2003'te NPT'den çekildiğini açıklamıştır. ${ }^{62}$

NPT'den çekilme kararı Kuzey Kore'ye yönelik eleştirileri artırmış ve "Altılı Görüşmeler" (Six-Party Talks-SPT) olarak adlandırılan çok taraflı müzakere sürecinin başlamasına sebep olmuştur. Kuzey Kore'yi ABD, Güney Kore, ÇHC, Rusya ve Japonya ile aynı masada bir araya getiren bu süreç, son dönem Kuzey Kore diplomasisinin en önemli meselesidir. Bölgede nükleer enerjinin kullanımından kaynaklanan devletlerarası anlaşmazlıkları barışçıl biçimde çözme amacı çerçevesinde yürüyen bu süreç, Ağustos 2003'te yapılan fakat bir sonuca ulaşamayan birinci tur müzakereleriyle başlamıştır. 2004 yılı içerisindeki ikinci ve üçüncü tur görüşmelerin kazanımları da yüzeysel kalmıştır. Fakat 2005-2007 yılları arasında gerçekleştirilen dördüncü, beşinci ve altıncı tur müzakerelerde sonuç almaya oldukça yaklaşılmış, hatta belirli miktarda benzin yardımı ve ABD ve Japonya'nın Kuzey Kore ile ilişkilerinin normalleşmesi karşılığında Pyongyang yönetiminin nükleer çalışmalarını durdurması kararı dahi alınmıştır. Fakat taraflar arasındaki güven eksikliği, sürecin başarıyla sonuçlanmasına engel olmuştur. Görüşmelerin kopmasına neden olan husus, Kuzey Kore’nin 2009 yılında uzaya uydu yerleştirme çalışmasına girişmesidir. Bu hamle, kıtalararası balistik füze teknolojisinin ilk adımı olarak değerlendirilerek, SPT ülkelerinde rahatsızlık yaratmıştır. Öyle ki bu hamleye, hem dönemin ABD Başkanı Barack Obama ihlallerin karşılıksız kalmayacağını açılayarak sert tepki göstermiş ${ }^{63}$ hem de BM Güvenlik Konseyi Kuzey Kore’nin bu eylemini kınayan ve bu ülke üzerindeki yaptırımların artırılmasını öngören bir deklarasyona imza atmıştır. ${ }^{64}$ Bu gelişmelerin bir sonucu olarak Kuzey Kore Nisan 2009'da SPT görüşmelerinden çekilmiş, tüm nükleer enerji denetçilerini ülkeden çıkartmış ve nükleer programına yeniden hız verdiğini resmî olarak açıklamıştır. Nitekim SPT'den çekilinmesinden

62 Rajaram Panda, “North Korea's Nuclear Policy: Domestic Determinants, Strategy and Future”, Journal of Comparative Asian Development, Cilt 10, No 2, 2011, s.229-230.

63 "Remarks by President Barack Obama in Prague as Delivered", 5 Nisan 2009, https://www.whitehouse.gov/the-pressoffice/remarks-president-barack-obama-prague-delivered (Erişim Tarihi 19 Ekim 2016).

64 "Security Council Condemns Launch by Democratic People’s Republic of Korea, Agrees to Adjust Travel Ban, Assets Freeze, Arms Embargo Imposed in 2006”, 13 Nisan 2009, http://www.un.org/press/en/2009/sc9634.doc.htm (Erişim Tarihi 19 Ekim 2016). 
bir ay sonra Kuzey Kore nükleer silah geliştirdiğini tüm dünyaya duyurmuştur. ${ }^{65} \mathrm{Bu}$ anlamda, sorunun görüşmeler yoluyla çözümüne yönelik çabalar sonuçsuz kalmıştır ve Kuzey Kore nükleer test ve çalışmalarını halen sürdürmektedir.

$\mathrm{Bu}$ kapsamda, nükleer alandaki çalışmaların, Kuzey Kore açısından getirdiği mali yükün yanı sıra, ülkenin uluslararası kamuoyu tarafından defalarca kınanmasına sebep olduğu göze çarpmaktadır. Ancak bu olumsuz etkilere karşın Kuzey Kore yönetimi söz konusu nükleer politikayı devam ettirmekte ısrarlı davranmaktadır. Bu noktada Kore'nin ısrarlı tavrında etkili olan dört ana etkenden bahsedilmelidir. $\mathrm{Bu}$ etkenlerden birincisi diplomasi kaynaklıdır; Kuzey Kore nükleer programını uluslararası diplomaside ağırlık ve itibar arayışının bir parçası olarak uygulamaktadır. Gerçekten de Cuçe rejimi açısından nükleer silahlanma programı hem müzakere masasına daha güçlü oturmak ve genel olarak uluslararası politikada daha etkili bir rol oynayabilmek için hem de ABD'yi pazarlıklara daha kolay çekebilmek ve ondan taleplerde bulunabilmek adına kullanışlı bir unsurdur. ${ }^{66}$ Aynı zamanda bu politika Kuzey Kore'nin anti-emperyalist ve anti-Amerikan duruşu için de hem içeriye hem de tüm dünyaya dönük verimli bir propaganda aracıdır ki, bu yöndeki propaganda da Cuçe ideolojisinin özünü oluşturmakta, ona temel karakterini vermektedir. ${ }^{67}$

Nükleer politikanın ikinci varoluş sebebi askeri kaynaklıdır. Kuzey Kore nükleer programını askeri öncelikli politikanın bir gereği olarak uygulamaktadır. İfadesini, dış dünyaya, özellikle de Batılı ülkelere karşı her zaman belirgin bir güvensizlikte bulan Cuçe öğretisi, nükleer silahlanma programını ciddi bir caydırıcllık oluşturarak ülkenin korunmasını kusursuz hale getirebilmek için desteklemektedir. Bu bakış açısında Batı́nın Kuzey Kore yönetimini devirmek ve onu Güney Kore’nin sistemine çekebilmek arzusu içinde bulunduğuna, nükleer politikanın da bu tehlikelere karşı dengeyi sağlamak için gerekli olduğuna dair bir inanç söz konusudur. Söz konusu yaklaşım kendisini Kuzey Kore yönetimince, $\mathrm{ABD}$-Kuzey Kore ilişkileri normalleşse dahi $\mathrm{ABD}$ nükleer tehdidinin en küçük bir etkisi kaldığı müddetçe Pyongyang'ın nükleer silahlanma politikasından herhangi bir dönüş yapılmayacağının açıkça vurgulanmasında hissettirmektedir. Bu anlamda, askeri öncelikli bakış açısının Kuzey Kore’ye dönük her türlü tedbirin askeri yöntemlerle ve artan sertleşme politikalarıyla karşılanmasını öngördüğü notunu düşmek de yerinde olacaktır. ${ }^{68}$

Kuzey Kore’nin takip ettiği nükleer programın üçüncü sebebi ise ekonomiktir. Ülkenin aşılamayan azgelişmişliği ve özellikle 1990 'lı yıllardan beri tecrübe ettiği yoksulluk sarmalında, ABD’li bazı uzmanlar Kuzey Kore liderliğinin nükleer silahlanma kartını dışarıdan yardım alabilmek için bir "şantaj aracı" olarak kullandığını ileri sürmektedir. ${ }^{69}$ Bu bakış açısına göre, Pyongyang yönetiminin ulusal nükleer programını geliştirmeye ve hayata geçirmeye dönük adımlarının Batılı ülkelerin dış yardım teklifleriyle karşılanması durumu söz konusudur. Farklı bir söylemle, Batılı hükümetlerin Kore'nin nükleer silahlanma politikasına karşı bir tür ekonomik "yatıştırma politikası" izlemeyi tercih etmeleri, Kuzey Kore'nin bu yöndeki girişimlerini daha da güçlendirmekte ve onu devamlı hale getirmektedir. Bu açıdan, Kuzey Kore yönetimi bir taraftan ekonomik yardım karşılığında nükleer politikasında değişim vadetmekte ve bu sayede belirli kazanımlar elde edebilmekte, ancak diğer taraftan silahlanma programını kendi belirlediği şartlarda istikrarlı bir biçimde devam ettirebilmektedir. ${ }^{70}$

65 Panda, "North Korea's Nuclear Policy”, s.234-235.

66 Kang, "The Lens of Juche”, s.56.

67 Habib, “Rogue Proliferator?”, s.2833.

68 Panda, "North Korea’s Nuclear Policy”, s.234-235.

69 Mustafa Kibaroğlu, “Kuzey Kore’nin Nükleer Silah Programı: Sebepler ve Sonuçlar”, Uluslararası İlişkiler, Cilt 1, No.1, 2004, s.167-168.

70 Panda, “North Korea's Nuclear Policy”, s.230. 
Kuzey Kore'nin nükleer programının altında yatan sonuncu ve belki de en önemli sebep ise iç siyasi yapıyı ayakta tutabilmek kaygısıdır. Cuçe yönetimi Sovyetler Birliği'nde izlenilen reform sürecinin sosyalist rejimin ortadan kalkmasıyla sonuçlanmasını dikkatle gözlemlemiş ve aynı gidişatın Kore'de de yaşanmaması için tüm maliyetine karşın nükleer silahlanma çalışmalarını sürdürmeyi tercih etmiştir. Zira nükleer silahlanma politikası Kuzey Kore'de bürokraside ve toplumsal yapıda baştan aşağı katı bir disiplin havasının hâkim olmasını sağlamakta, ülkeyi tüm katmanlarıyla teyakkuz halinde tutmaktadır. Böylesi bir olağanüstü hâl durumu çerçevesinde de hem toplumsal reform taleplerinin önü kesilebilmekte hem de ekonomik kaynakların önemli oranda silahlanmaya aktarılması, yani büyük askeri harcamaların meşru kılınması sağlanmaktadır. Bu bağlamda nükleer silahlanma programı askeri öncelikli politikanın ve daha genel bir anlamda Cuçe öğretisinin devamına hizmet eden kritik bir unsur olarak öne çıkmaktadır. ${ }^{71}$

$\mathrm{Bu}$ sebeplerden ötürü, Kim iktidarının üçüncü kuşak temsilcisi Kim Jong-un da, şaşırtıcı olmayan biçimde, aynı politikaları devam ettirme yönelimindedir. Kim Jong-un yayınladığı ilk resmî yeni yıl mesajında askeri öncelikli politikaya özellikle vurgu yapmış, reform ya da açıklık gibi konulara ise hiç değinmemiştir. Ayrıca Nisan 2012'de düzenlenen KİP konferansında Cuçe'ye bağlılığın altı bir kez daha çizilirken, Kim Il-sung'un doğumunun yüzüncü yıl anmalarında Cuçe’yi ve militarist politikaları sürdürme kararlılığı dünyaya bir kez daha resmî olarak ilan edilmiştir. BM Güvenlik Konseyi’nden gelen protestolara rağmen nükleer programına ve füze çalışmalarına tüm yoğunluğuyla devam eden Kim Jong-un, bu bağlamda, geleneksel ideolojik yaklaşıma ve politikalara sadakatini ortaya koymaktadır. $^{72}$

Kim Jong-un liderliğinde KİP Merkez Komitesinin Mart 2013 tarihinde düzenlenen toplantısında ekonomik yapılanma ile nükleer silahlanma projesinin eşzamanlı olarak yürütülmesi yönünde karar alınmış, ${ }^{73}$ Ocak 2016 'da ise Kuzey Kore ilk hidrojen bombası denemesini başarıyla gerçekleştirmiştir. ${ }^{74}$ Jong-un seleflerinin ABD ile Güney Kore arasındaki yakın askeri ilişkilere yönelik tepkilerini de artırarak sürdürmektedir. Pyongyang yönetimi, Mart 2017'de ABD ile Güney Kore'nin Foal Eagle adlı askeri tatbikatına yönelik olarak ön alıcı bir nükleer müdahalede bulunabileceği uyarısını yapmış, ${ }^{75}$ Nisan ayında da, ABD ve ÇHC Başkanları Donald Trump ile Şi Cinping’in görüşmesinin hemen öncesinde balistik füze denemesi gerçekleştirmiştir. ${ }^{76} \mathrm{ABD}$ 'nin bu adıma karşılık yaptığı hamleler üzerine Kuzey Kore'nin, ABD'nin eylemleri karşısında termonükleer bir savaşın her an başlayabileceğini bildirmesi de yine dikkate değer ve Kim Jong-un'un bu yöndeki tutarlı tavrına bir örnek olarak anlaşılmalıdır. ${ }^{77}$

71 Habib, “Rogue Proliferator?”, s.2831.

72 Park, "Policies and Ideologies", s.10-11.

73 "Report on Plenary Meeting of WPK Central Committee", 31 Mart 2013, https://kcnawatch.co/ newstream/1451895560-172035864/report-on-plenary-meeting-of-wpk-central-committee/ (Erişim Tarihi 15 Nisan 2017).

74 "North Korea Nuclear: State Claims First Hydrogen Bomb Test", 6 Ocak 2016, http://www.bbc.com/news/worldasia-35240012 (Erişim Tarihi 15 Nisan 2017).

75 "North Korea Threatens Nuclear Strike over U.S.-South Korean Exercises", 7 Mart 2016, http://edition.cnn. com/2016/03/06/asia/north-korea-preemptive-nuclear-strike-threat/ (Erişim Tarihi 15 Nisan 2017).

76 "North Korea Fires Ballistic Missile as Trump, Xi Prepare to Meet”, 6 Nisan 2017, http://edition.cnn.com/2017/04/04/ asia/north-korea-projectile/ (Erişim Tarihi 15 Nisan 2017).

77 "North Korea Warns 'Thermonuclear War' may Break Out any Moment”, 14 Nisan 2017, http://nypost. com/2017/04/14/china-says-north-korea-tension-has-to-be-stopped-from-reaching-irreversible-stage/ (Erişim Tarihi 15 Nisan 2017). 


\section{Sonuç}

Cuçe ideolojisi, Kuzey Kore'nin hem devlet olarak varoluşunda, hem de hayata geçirdiği politik hamlelerde belirleyici bir rol oynamaktadır. Bu ideoloji, ülkenin siyasi ve ekonomik yapısını doğrudan şekillendirmekte, katı devletçi, lidere mutlak itaati öngören, militarist ve totaliter bir yönetim mantığını hâkim kılmaktadır. Böylesi bir yapının dış politikaya yaklaşımı ise beklenilebileceği gibi sert söylem ve tedbirleri öngörmektedir. Öyle ki Kuzey Kore bugün dünyanın en yoksul ülkelerinden biri olmasına rağmen militarist dış politika adımlarıyla sadece yakın çevresinde değil, küresel düzlemde adından söz ettirebilmektedir.

Mevcut lider Kim Jong-un'un Cuçe'nin temel kabullerine bağlılığı ve bu ilkeler doğrultusunda ortaya koyduğu politikalar ise ülkedeki statükoyu korumaya yönelik eğiliminin sarih bir göstergesi olarak anlaşılabilir. Zira Jong-un'un tıpkı selefleri gibi çoksesliliğe izin vermeyen bir yönetim tarzı takip etmesi, ülkede köklü değişimi öngören bir toplumsal muhalefetin oluşması ve başarı kazanmasını son derece zorlaştırmaktadır. Bu anlamda Kuzey Kore'de Cuçe rejiminin tasfiyesi büyük ölçüde dışarıdan gelecek bir etkiye bağlıdır ki Pyongyang yönetiminin uyguladığı şüpheci dış politika da bu tehlikenin devre dışı bırakılması temeline dayalıdır. Dolayısıyla Kuzey Kore’nin dış politik yönelimleri Cuçe ögretisinin asli kabullerinin bir sonucu ve bu ideolojiyi ülkede egemen söylem olarak tutmanın bir yolu olarak göze çarpmaktadır. Bununla birlikte, karşılıklı bağımlılığın arttığı ve toplumlararası etkileşimi engellemenin neredeyse imkânsız hale geldiği çağdaş dünya şartları dâhilinde $C u c ̧ e$ rejiminin izolasyoncu yönetim tarzını devam ettirmesinin her geçen gün daha da zorlaşacağını belirtmek yanlış olmayacaktır. 